MAJOR-ELEMENT GLASS COMPOSITIONS OF TEPHRA FROM THE CIRCA 3.6 KA ERUPTION OF ANIAKCHAK VOLCANO, ALASKA PENINSULA, ALASKA

Kristi L. Wallace, Leslie A. Hayden, and Christina A. Neal

Raw-Data File 2017-9

$\$ 1.00$

This report has not been reviewed for technical content or for conformity to the editorial standards of DGGS.

December 2017

State of Alaska

Department of Natural Resources

Division of Geological \& Geophysical Surveys 
STATE OF ALASKA

Bill Walker, Governor

DEPARTMENT OF NATURAL RESOURCES

Andrew T. Mack, Commissioner

DIVISION OF GEOLOGICAL \& GEOPHYSICAL SURVEYS

Steve Masterman, State Geologist \& Director

Publications produced by the Division of Geological \& Geophysical

Surveys are available for free download from the DGGS website

(dggs.alaska.gov). Publications on hard-copy or digital media can be

examined or purchased in the Fairbanks office:

Alaska Division of Geological \& Geophysical Surveys (DGGS)

3354 College Road | Fairbanks, Alaska 99709-3707

Phone: 907.451 .5010 | Fax 907.451.5050

dggspubs@alaska.gov $\mid$ dggs.alaska.gov

DGGS publications are also available at:

Alaska State Library, Historical

Collections \& Talking Book Center

395 Whittier Street

Juneau, Alaska 99801

Alaska Resource Library and

Information Services (ARLIS)

3150 C Street, Suite 100

Anchorage, Alaska 99503

\section{Suggested citation:}

Wallace, K.L., Hayden, Leslie A., and Neal, C.A., 2017, Major-element glass compositions of tephra from the circa $3.6 \mathrm{ka}$ eruption of Aniakchak volcano, Alaska Peninsula, Alaska: Alaska Division of Geological \& Geophysical Surveys Raw Data File 2017-9, 9 p. http://doi.org/10.14509/29777
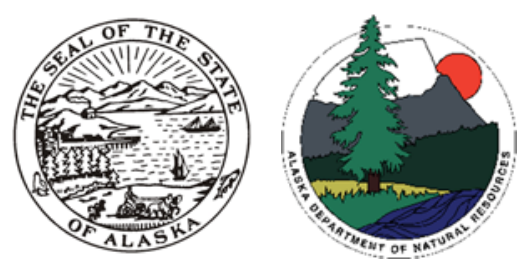


\title{
MAJOR-ELEMENT GLASS COMPOSITIONS OF TEPHRA FROM THE CIRCA 3.6 KA ERUPTION OF ANIAKCHAK VOLCANO, ALASKA PENINSULA, ALASKA
}

\author{
Kristi L. Wallace ${ }^{1}$, Leslie A. Hayden ${ }^{2}$, Christina A. Neal ${ }^{3}$
}

\begin{abstract}
This Raw Data File presents major-oxide glass geochemical results from the ca. 3.6 ka caldera-forming eruption of Aniakchak volcano, Alaska. These data are part of a larger effort to identify and characterize tephra deposits from the largest eruptions in Alaska for use as geochronological marker horizons. Aniakchak is one of at least 29 volcanoes in Alaska that has had multiple large tephra-producing eruptions. Other deposit and sample metadata including geospatial distributions of this tephra deposit are held in the Alaska Volcano Observatory's online database, the Geologic Database of Information on Volcanoes in Alaska (GeoDIVA), and will be linked to these new geochemical data once published. Products included in this data release are background information on the larger project, methods of sample collection, processing, analysis, and data reduction spreadsheets showing 1) raw point major-oxide data, 2) normalized and averaged major-oxide data, and 3) basic sample metadata.
\end{abstract}

\section{INTRODUCTION}

Aniakchak volcano is a Pleistocene to Holocene volcano of the Alaska-Aleutian Arc (Figure 1). It has had at least two caldera-forming eruptions in postglacial time, Aniakchak I (CFE I) and Aniachak II (CFE II) (Miller and Smith, 1987). The modern Aniakchak caldera was formed during a large explosive eruption ca. $3.6 \mathrm{ka}$ cal BP (CFE II) that produced widespread tephra deposits (Figure 2) (Miller and Smith, 1977; Bacon and others, 2014). The ash cloud from this eruption was directed northward and fall deposits have been recognized in geologic outcrops along the Alaska Peninsula and mainland Alaska, as far as the Seward Peninsula (Kienle and Swanson 1983, Riehle and others, 1987; Begét and others 1992, and Dunning 2011). Bacon and others (2014) summarize previously published radiocarbon ages of the Aniakchak CFE II eruption and assign a preferred age of $3,660 \pm 70 \mathrm{cal}$ yr BP $\left(3,430 \pm 70{ }^{14} \mathrm{C}\right.$ yr BP, uncalibrated). The Aniakchak CFE II eruption is considered an important stratigraphic marker horizon in western Alaska. The focus of this data release is major-oxide glass geochemical results from proximal Aniakchak CFE II

\footnotetext{
${ }^{1}$ U.S. Geological Survey, Alaska Volcano Observatory, 4230 University Drive, Suite 100, Anchorage, AK 99508, ORCID \#00000002-0962-048X

${ }^{2}$ U.S. Geological Survey, Volcano Science Center 345 Middlefield Rd., Menlo Park, CA 94025, ORCID \#0000-0001-7420-0476

${ }^{3}$ U.S. Geological Survey, Hawaiian Volcano Observatory, P.O. Box 51, 1 Crater Rim Drive, Hawaii National Park, HI 96718, ORDIC \#0000-0002-7697-7825
} 
eruptive products. These data are considered reference materials for use in geochemical correlation to this eruption. 


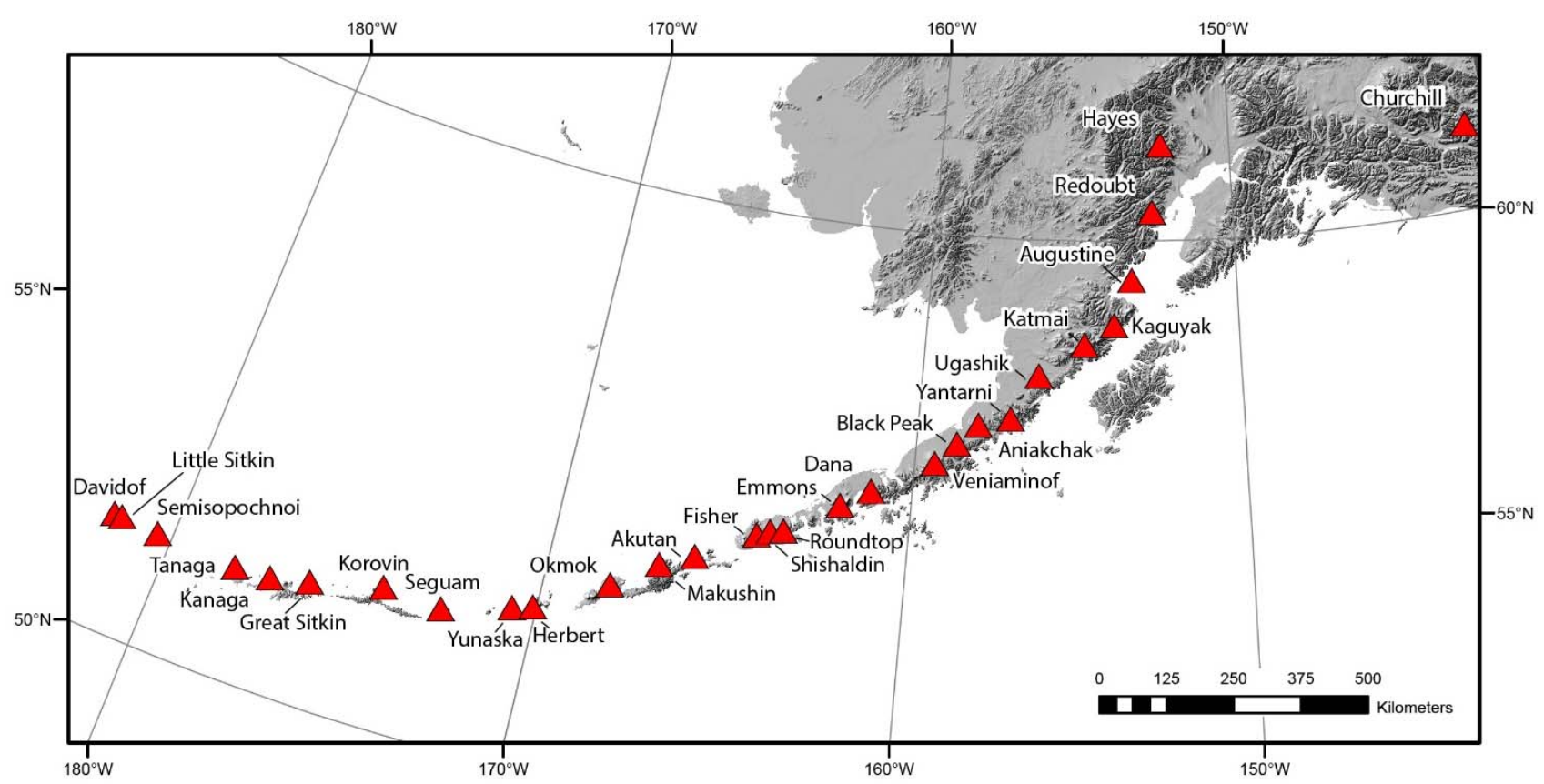

Figure 1. Map of the Aleutian Volcanic Arc, Alaska showing the locations of volcanoes that have produced regionally significant tephra deposits during the Holocene.

\section{BACKGROUND}

Deposition of volcanic ash onto a landscape is essentially instantaneous in geologic time.

If the ages of volcanic-ash layers are known or if the ashes can be correlated to deposits of known age, they are excellent time-stratigraphic markers used in volcanology, archaeology, and paleoclimate research. Volcanic-ash deposits from large tephra-producing eruptions (e.g. caldera-forming eruptions) are most likely to be widely-distributed and therefore, more often encountered in field studies. Compilation of physical and chemical characteristics, geospatial distribution, and age of these deposits can support research in many disciplines across large regions and even across continents.

As part of a larger effort to construct a comprehensive database of Alaska tephras, this project is intended to highlight Holocene-age tephra deposits of the largest eruptions from Alaska volcanoes. We have identified the largest Holocene-age tephra-producing eruptions from approximately 29 source volcanoes, many of which have had multiple large tephra-producing eruptions (Figure 1). Many of these deposits do not yet have glass geochemistry, which is needed to conclusively correlate deposits. Therefore, we are working to obtain samples from both proximal and distal locations for these extensive deposits and geochemically analyze these samples to aid in improving correlation potential with other unidentified deposits. These such 
data will be tagged in the Alaska Tephra Database as "reference" datasets and are intended to represent a comprehensive analysis of known source materials.

We envision that researchers will be able to query our online database, the Geologic Database of Information on Volcanoes in Alaska (GeoDIVA), using text or spatial searches and quickly download and visualize sample location, glass geochemistry, and geospatial tephra distribution of large eruptions that may have impacted their area of study. Mulliken and others (2017, written commun.) have compiled all published Alaska ashfall extents in an Arc geodatabase that will soon be released; this data compilation will serve as the starting point for future on-line geospatial queries of known ashfall extents. Cameron and others (written commun., 2017) have completed data entry for over 2,000 tephra glass analyses in preparation for the Alaska Tephra Database searchable on-line database release. The Aniakchak glass data presented here is the first of several large-eruption tephra datasets that we plan to add to the growing Alaska Tephra Database. This product will aid those working on tephra-related stratigraphic issues in Alaska to enable rapid and confident determinations of which tephra deposits are relevant to a given study area and what geochronologic constraints are currently possible. Information from the database will be useful for assessing tephra-fall hazards associated with these large and important eruptions.

\section{SAMPLE COLLECTION METHODS FOR ALL LARGE ERUPTION DATASETS}

When available, this project uses legacy samples collected from various completed projects that are stored in archives. The ideal sample type for this project is coarse grained (lapilli), bulk proximal fallout that includes all components of the deposit so that the entire range of compositions can be analyzed. If proximal fallout is not available, clasts from proximal pyroclastic flows are used. In addition, distal samples of confirmed fallout are included in the dataset when possible. Bulk glass composition is considered to be constant throughout a fallout deposit (regardless of distance from source). Minor glass sub populations may be observed and characteristic of an eruption. Confirming sub populations in proximal deposits where more material is available to characterize encourages those analyzing distal deposits, where only small samples (volume and particle size) may be available, to be mindful in not discarding small numbers of analyses that look like outliers.

\section{ANIAKCHAK TEPHRA SAMPLE COLLECTION, PROCESSING AND ANALYSIS METHODS}

\section{Sample collection}

For this Aniakchak ca 3.6 ka deposit dataset, tephra samples were collected from a single coastal bluff outcrop along the Bering Sea (station ID: NA96-3, 57.05235N, 158.62377W, 
WGS84), $33 \mathrm{~km}$ west-northwest of the center of the Aniakchak crater (Figure 2). The outcrop contains both pyroclastic flow $(15 \mathrm{~m})$ and underlying fallout deposits $(25 \mathrm{~cm})$ (Figure 3 ).

Stratigraphic locations of samples used in this data release are shown in Figure 4. All available

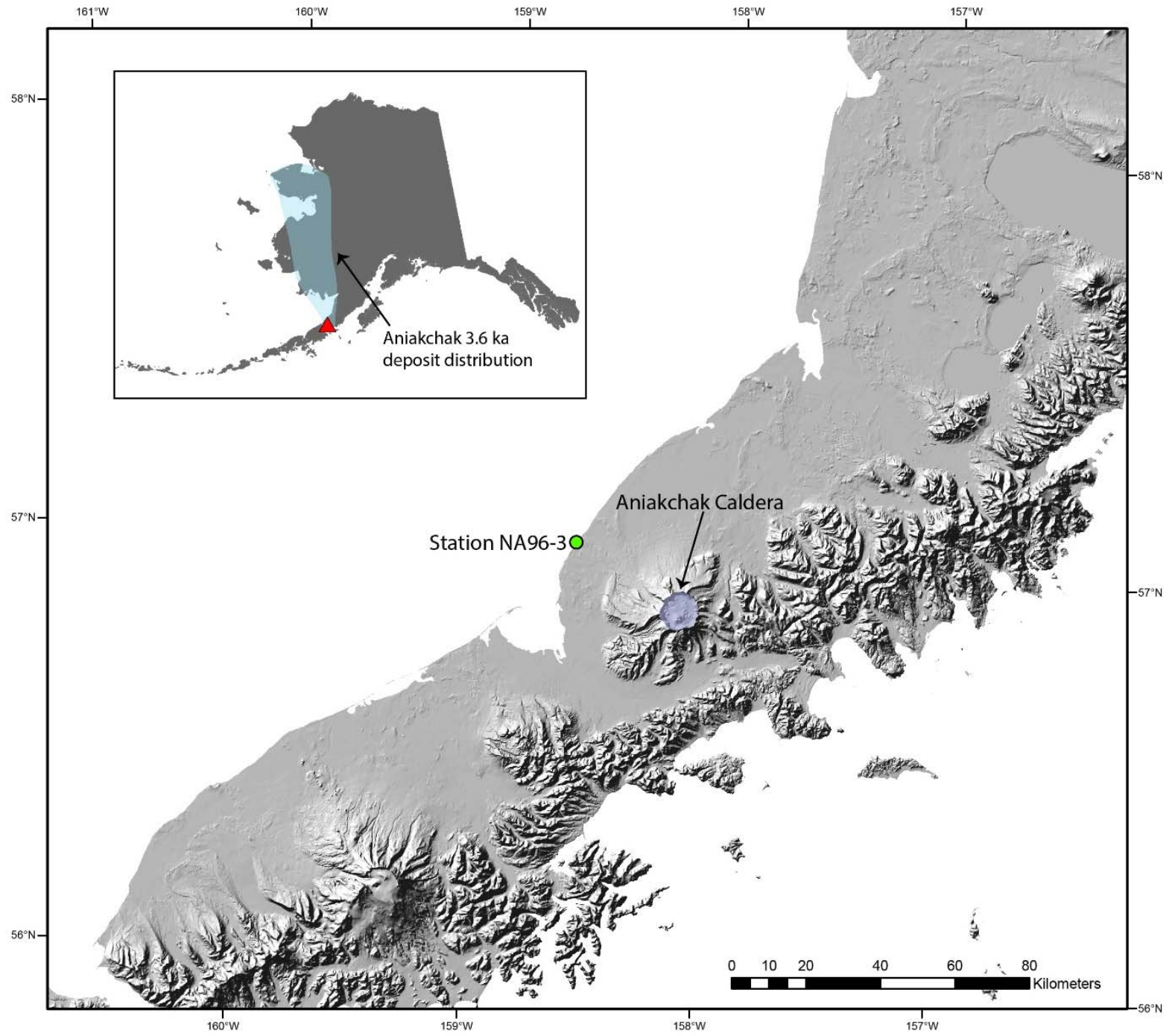

sample metadata are entered into GeoDIVA geochemical database and are linked with these geochemical data, available on-line at https://avo.alaska.edu/geochem/index.php.

Figure 2. Location map showing Aniakchak volcano on the Alaska Peninsula and field station NA96-3, where samples, used in this data release, were collected. Index map shows the interpreted distribution of tephra-fall deposits from the ca. $3.6 \mathrm{ka}$ caldera-forming eruption of Aniakchak volcano compiled by Katherine Mulliken (AK-DGGS) from Kienle and Swanson (1983), Begét and others (1992), and Dunning (2011). 


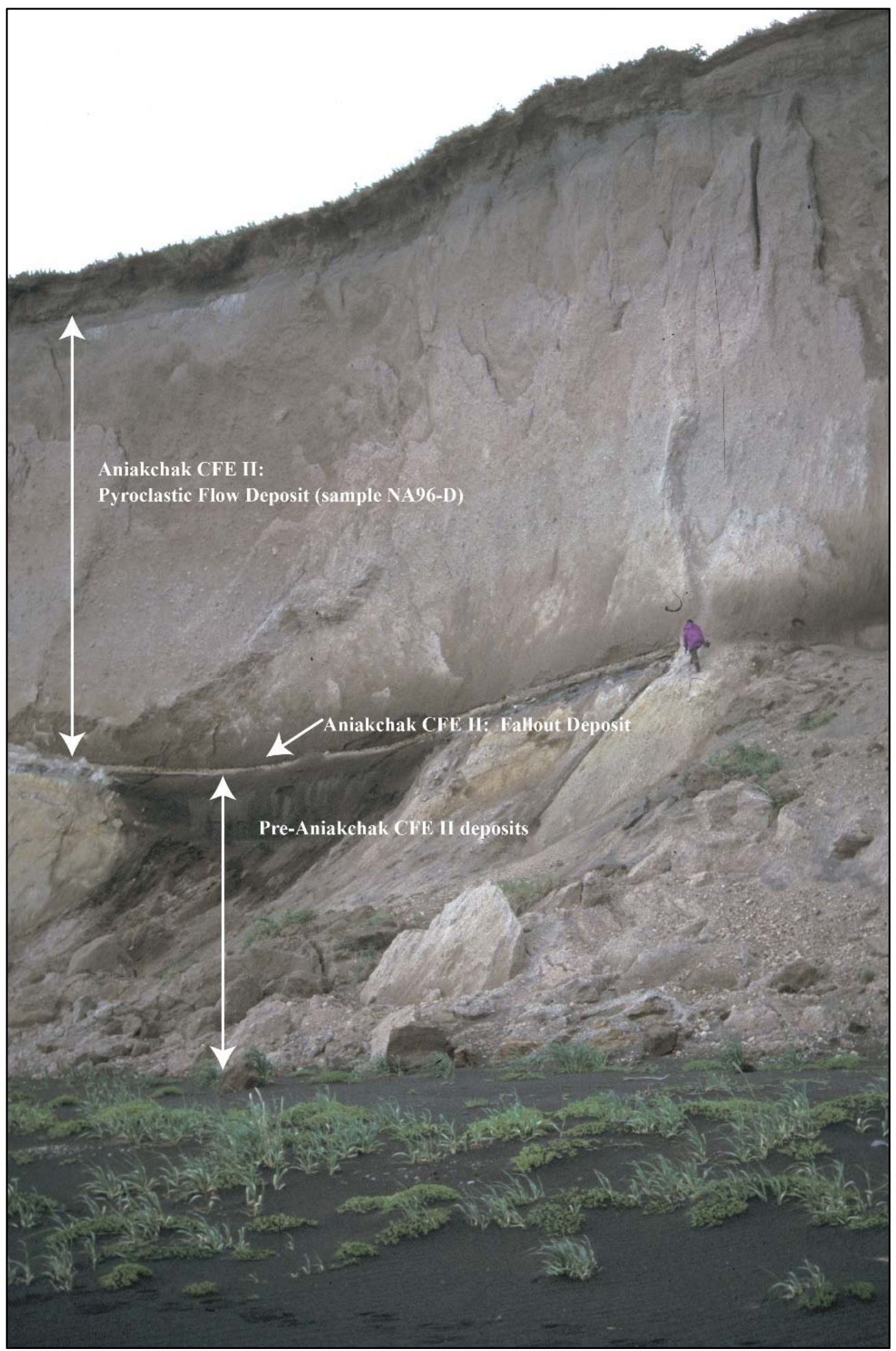

Figure 3. Overview photograph of field station NA96-3, $33 \mathrm{~km}$ west-northwest of Aniakchak volcano showing the stratigraphic position of pyroclastic deposits from the ca. $3.6 \mathrm{ka}$ caldera-forming eruption. Person in purple jacket for scale. AVO Image Database URL: http://www.avo.alaska.edu/images/image.php?id=112841 


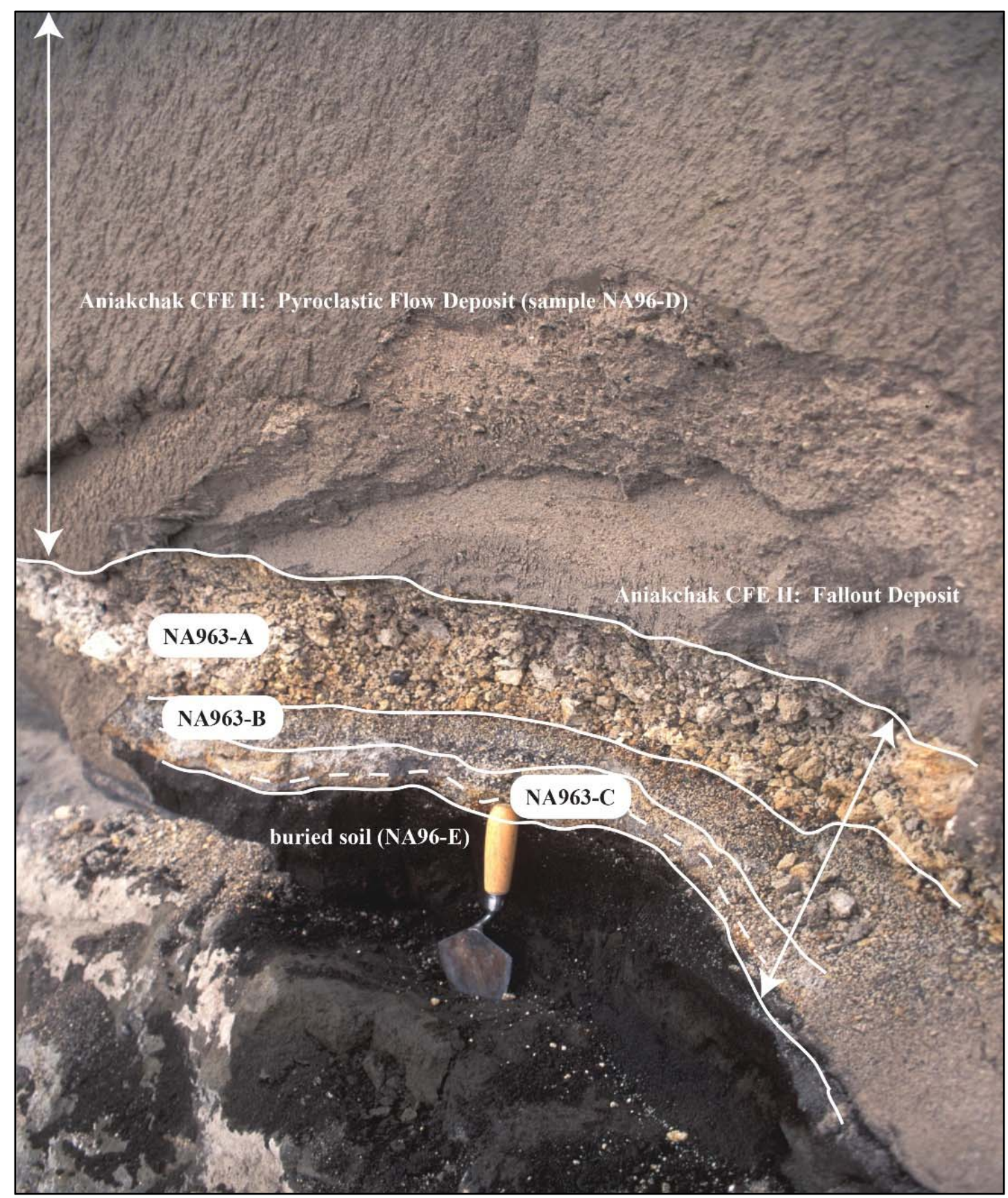

Figure 4. Photograph from field station NA96-3, $33 \mathrm{~km}$ west-northwest of Aniakchak volcano showing the stratigraphic locations and sample names used in this data release. Hand trowel for scale. AVO Image Database URL:

http://www.avo.alaska.edu/images/image.php?id=112851

\section{Sample processing}

All samples were processed in the U.S. Geological Survey Alaska Tephra Laboratory \& Data Center in Anchorage, Alaska. Coarse-grained samples ( $>2 \mathrm{~mm}$ in diameter) were hand- 
selected to make mounts for electron probe microanalysis (EPMA). Finer grained samples $(<2$ $\mathrm{mm}$ in diameter) were wet sieved into three size fractions mainly to remove fine-grained ash from the surfaces of the coarser material. Material in the size fraction $\geq 0.125 \mathrm{~mm}$ was used to make bulk grain mounts for EPMA. Standard polished probe mounts were made professional by Mann Petrographics, New Mexico.

\section{Sample analysis}

Major-element glass analyses were conducted using wavelength dispersive techniques with a 5-spectrometer JEOL 8900R electron probe microanalyzer (EPMA) at the USGS in Menlo Park, Calif. Concentrations were determined with the CIT-ZAF reduction scheme (Armstrong, 1995). Glass analyses used a 5 - $\mu \mathrm{m}$-diameter beam with $5 \mathrm{nA}$ current and $15 \mathrm{kV}$ accelerating potential. Reported glass compositions are the averages of 15-30 spot analyses or fewer if multiple populations were found within a single sample; background intensities were determined 1-3 times for each grain. Count times were $10 \mathrm{~s}$ for $\mathrm{Na}$ (which was analyzed first to reduce Naloss), $10 \mathrm{~s}$ for $\mathrm{S}$ and $\mathrm{Cl}$, and $30 \mathrm{~s}$ for all other elements. During analysis, sets of 5-10 replicate analyses of glass standards RLS-75 (rhyolite glass) and VG-2 (basaltic glass) (Jarosewich and others, 1979) were performed to monitor instrument drift. Natural glass and mineral standards were used for calibration: RLS-132 for Si; basaltic glass VG-2 for Fe, Mg, and Ca; Orthoclase 1 for $\mathrm{K}$ and $\mathrm{Al}$; Tiburon albite for $\mathrm{Na}$; $\mathrm{Mn} 2 \mathrm{O} 3$ for $\mathrm{Mn}$; $\mathrm{TiO} 2$ for $\mathrm{Ti}$; sodalite for $\mathrm{Cl}$; and Wilberforce apatite for P. Standard deviations of averages of multiple spot analyses for single unknown samples are generally within those listed for working standards. Point data for all glass analyses (including standards) as well as a summary of normalized averaged data for all glass sample analyses are given in this data release.

\section{Data reduction}

Once electron microprobe data are acquired and downloaded as raw data in a spreadsheet they are filtered to reduce unwanted data. The workflow describing how raw data are filtered for final submission is presented below.

All geochemical data acquired by EMPA were subject to rejection based on the following criteria.

1. Analyses totaling $<80 \%$ (bad analysis)

2. Analyses with $\mathrm{MgO}>15 \%$ (mafic mineral)

3. Analyses with $\mathrm{Al}_{2} \mathrm{O}_{3}>20 \%$ (feldspar)

4. Analyses with $\mathrm{FeO}>15 \%$ (mafic mineral) 
All analyses totaling $<90 \%$ were subject to rejection unless they appeared to represent good glass analyses (once normalized) compared to other analyses in the same sample with totals $>90 \%$ (similarity among major elements). All raw point data are preserved as part of this publication, allowing anyone to see which points were deleted and the justification. This also allows data users to recalculate averaged values based on analysis points of their choosing.

These criteria were used as a first approximation of the data and allowed for the identification and elimination of most micro-mineral analyses. In addition, all sample data were inspected individually to identify other micro-mineral phases. Geochemical mineral identification was based on values given in Deer and others (1996).

Although glass standards were analyzed prior to each analysis session, it was not uncommon to acquire unusable analyses due to, for example: 1) analyzing thin regions where the electron beam passes through the material and into the underlying epoxy or mineral, 2) inadvertently analyzing micro-mineral phases, and/or 3) analyzing near the edge of a shard resulting in analyses of nearby materials (minerals or epoxy). Most of these data were identified using the filtering criteria and eliminated from the dataset.

\section{EXPLANATION OF DATA FILES}

Raw point data, normalized data, and summary data (average and standard deviation) are given together in accompanying files and organized by sample ID.

1. Raw point data for all samples and working standards in the order they were run on the electron microprobe. File contains normalized (to 100\%) point data omitting points that have been filtered out (e.g. mineral inclusion, epoxy, low or high totals, etc.).

2. Sample metadata (description, location, etc.) and a summary of normalized averages and 1 sigma standard deviations of major oxides of $\mathrm{n}$ points for each sample. Each compositional-data worksheet is organized in the same fashion. Oxides are presented in weight percent.

3. Metadata files for each spreadsheet contain definitions for each data field.

\section{ACKNOWLEDGMENTS}

This project is funded through the U.S. Geological Survey Volcano Science Center, and this raw data file (RDF) is published through the State of Alaska Division of Geological \& Geophysical Surveys (DGGS) with funding provided under USGS Volcano Hazard Program/DGGS cooperative agreement G16AC00165. The authors would like to thank Katherine Mulliken and Cheryl Cameron at DGGS for their guidance formatting the dataset for quick inclusion in the Geologic Database of Information on Volcanoes in Alaska (GeoDIVA) and for support with producing map figures. 


\section{REFERENCES CITED}

Armstrong, J.T., 1995, CITZAF: a package of correction programs for the quantitative electron microbeam X-ray analysis of thick polished materials, thin films, and particles: Microbeam Analysis, v. 4, p. 177200.

Bacon, C.R., Neal, C.A., Miller, T.P., McGimsey, R.G., and Nye, C.J., 2014, Postglacial eruptive history, geochemistry, and recent seismicity of Aniakchak volcano, Alaska Peninsula: U.S. Geological Survey Professional Paper 1810, 74 p., http://dx.doi.org/10.3133/pp1810.

Begét, J.E., Mason, Owen, and Anderson, Patricia, 1992, Age, extent, and climatic significance of the c. 3400 BP Aniakchak tephra, western Alaska, USA: The Holocene, v. 2, no. 1, p. 51-56.

Deer, W.A., Howie, R.A., and Zussman, Jack ,1992, An introduction to the rock-forming minerals (2d ed.): Essex, England, Longman Scientific \& Technical, 696 p.

Dunning, H.A., 2011, Extending the applications of tephrochronology in northwestern North America: Alberta, University of Alberta, M.S. thesis, 187 p.

Jarosewich, Eugene, Nelen, J.A., and Norberg, J.A., 1979, Electron-microprobe reference samples for standard analysis: Smithsonian Contributions to the Earth Sciences, v. 22, p. 68-72.

Kienle, Juergen, and Swanson, S.E., 1983, Volcanism in the eastern Aleutian Arc: late Quaternary and Holocene centers, tectonic setting and petrology: Journal of Volcanology and Geothermal Research, v. 17, no. 1-4, p. 393-432.

Miller, T.P., and Smith, R.L., 1977, Spectacular mobility of ash flows around Aniakchak and Fisher calderas, Alaska: Geology, v. 5, p. 173-178.

Riehle, J.R., Meyer, C.E., Ager, T.A., Kaufman, D.S., and Ackerman, R.E., 1987, The Aniakchak tephra deposit, a late Holocene marker horizon in western Alaska, in Hamilton, T.D., and Galloway, J.P., eds., Geologic studies in Alaska by the U.S. Geological Survey during 1986: U.S. Geological Survey Circular 998, p. 19-22. 